\title{
20. X-RAY MINERALOGY STUDIES, LEG 67 (SITES 494-500): THE MIDDLE AMERICA TRENCH TRANSECT OFF GUATEMALA ${ }^{1}$
}

\author{
C. Latouche and N. Maillet, Institut de Géologie du Bassin d'Aquitaine (Laboratoire Associé au CNRS no 197), \\ Université de Bordeaux I, France
}

\begin{abstract}
Leg 67 sample sediments are mainly composed of biogenic carbonate and biogenic siliceous materials. Apart from calcite, crystallized minerals are scarce; however, they are better represented in sites near the continent and in all Quaternary sediments. These minerals are: quartz, feldspars, smectite, and, rarely, chlorite, dolomite, and zeolite.
\end{abstract}

\section{INTRODUCTION}

Mineralogy studies were carried out on all sites spread along a trench transect going from the Pacific Plate to the Guatemalan slope.

The results are presented for each site, from the south to the southwest and the north to the northeast.

\section{METHODS}

X-ray diffraction was employed in the analysis of 92 bulk samples using powders and in the mineralogical analysis of 92 fine-grained fractions $(<2-\mu \mathrm{m}$ calcium carbonate free fractions) using smear slides.

The samples studied belong principally to either siliceous or carbonate formations cored at seven drill sites on the Guatemalan margin (Fig. 1).

\section{Total Sediment}

Dried and pulverized samples of total sediment were analyzed according to the powder diagram method (Brown, Brindley, 1961). The abundances of quartz $(3.35 \AA)$ and feldspars (alkalines, $3.27 \AA$; plagioclases, $3.20 \mathrm{~A}$ ) were estimated in the X-ray diagrams as follows: trace: peak is just visible, or weak; present: peak is quite visible, or medium; and abundant: peak is easily measurable, or strong.

The proportion of carbonates was calculated by calcimetry (Bernard Calcimeter).

\section{Clay Fraction $(<2 \mu \mathrm{m})$}

Total sediments were treated with $\mathrm{HCl} \mathrm{N10.} \mathrm{After} \mathrm{repeated} \mathrm{wash-}$ ing in pure water, the $<2-\mu \mathrm{m}$ fractions were separated by settling. Each fraction was centrifuged, and the thick paste obtained was then spread across three slides with a spatula. The amount of clay per $\mathrm{cm}^{2}$ was dictated by the amount transferred to the three slides (Thorez, 1975). The first slide was scanned untreated, the second was saturated with ethylene glycol before analysis, and the third was heated at $550^{\circ} \mathrm{C}$ for $1 \mathrm{hr}$.

The diffractometer used was a Philips 1310; operating conditions were as follows: nickel-filtered, copper- $\mathrm{K}_{\alpha}$ radiation.

\section{RESULTS}

Generally speaking, the crystallized mineralogical phase, apart from the carbonates, is very limited and sometimes completely absent.

\section{Site 495 (Table 1)}

This hole is the farthest offshore on the ocean floor; the sediments cored are Miocene, Pliocene, and Quater-

\footnotetext{
${ }^{1}$ Aubouin, 1., von Huene, R., Init. Repts. DSDP, 67; Washington (U.S. Govt. Printing Office).
}

nary. Foraminiferal nannofossil chalk and ooze of the lower and middle Miocene formations (Samples 495$46-1,28-30 \mathrm{~cm}$ to $495-21-4,23-25 \mathrm{~cm}$ ) are carbonates (calcite, exclusively); quartz and feldspars are absent. In the $<2-\mu \mathrm{m}$ fraction, the argillaceous minerals, present here and there, are very badly crystallized smectites; only one layer of the lower Miocene (Sample 495-23-1, 21-24 cm) contains well-crystallized smectites.

The upper Miocene, Pliocene, and Pleistocene sediments (Samples 495-19-2, 110-112 cm to 495-4-3, 128$130 \mathrm{~cm}$ ) are siliceous mud. Quartz and feldspars (plagioclases), when they can be detected, are only present as traces; the $<2-\mu \mathrm{m}$ fraction contains no crystallized argillaceous minerals. Smectites were identified rarely.

\section{Site 500 (Table 2)}

This site is located in the trench axis, and the sediments collected are lower Miocene and Quaternary.

The Miocene sediments (Samples 500-15-5, 37-39 cm to $500-10-3,29-31 \mathrm{~cm}$ ) are foraminiferal nannofossil chalk and ooze averaging $80 \%$ calcite; no other mineral is identifiable by X-ray diffraction.

The Quaternary formations (Samples 500-8,CC, [25$28 \mathrm{~cm}$ ] to $500-1-3,13-15 \mathrm{~cm}$ ) are siliceous biogenic mud of only $8 \%$ to $5 \%$ carbonate and are characterized by traces of quartz but also by plagioclases in greater proportions. The clays are represented by some traces of smectite.

\section{Site 499 (Table 3)}

These holes are also situated on the floor of the trench. The formations drilled range from the lower and middle Miocene, the Pliocene, to the Quaternary.

Hole 499B. The lower Miocene sediments (Samples 499B-9,CC [17-19 cm] to 499B-2-2, 63-65 cm) are nannofossil chalk of $50 \%$ to $87 \%$ calcite and show no other minerals in the total sediment. Well-crystallized smectite is present in this $<2-\mu \mathrm{m}$ fraction.

Hole 499. The Miocene sediments (Samples 499-25-4, $84-86 \mathrm{~cm}$ to $499-23-3,105-107 \mathrm{~cm}$ ) are nannofossil chalk and ooze of $63 \%$ to $69 \%$ calcite, and in the $<2$ $\mu \mathrm{m}$ fraction they show well-crystallized smectites.

Pliocene and Quaternary sediments (Samples 499-22$3,57-59 \mathrm{~cm}$ to $499-1-1,129-131 \mathrm{~cm}$ ) contain pelagic, 


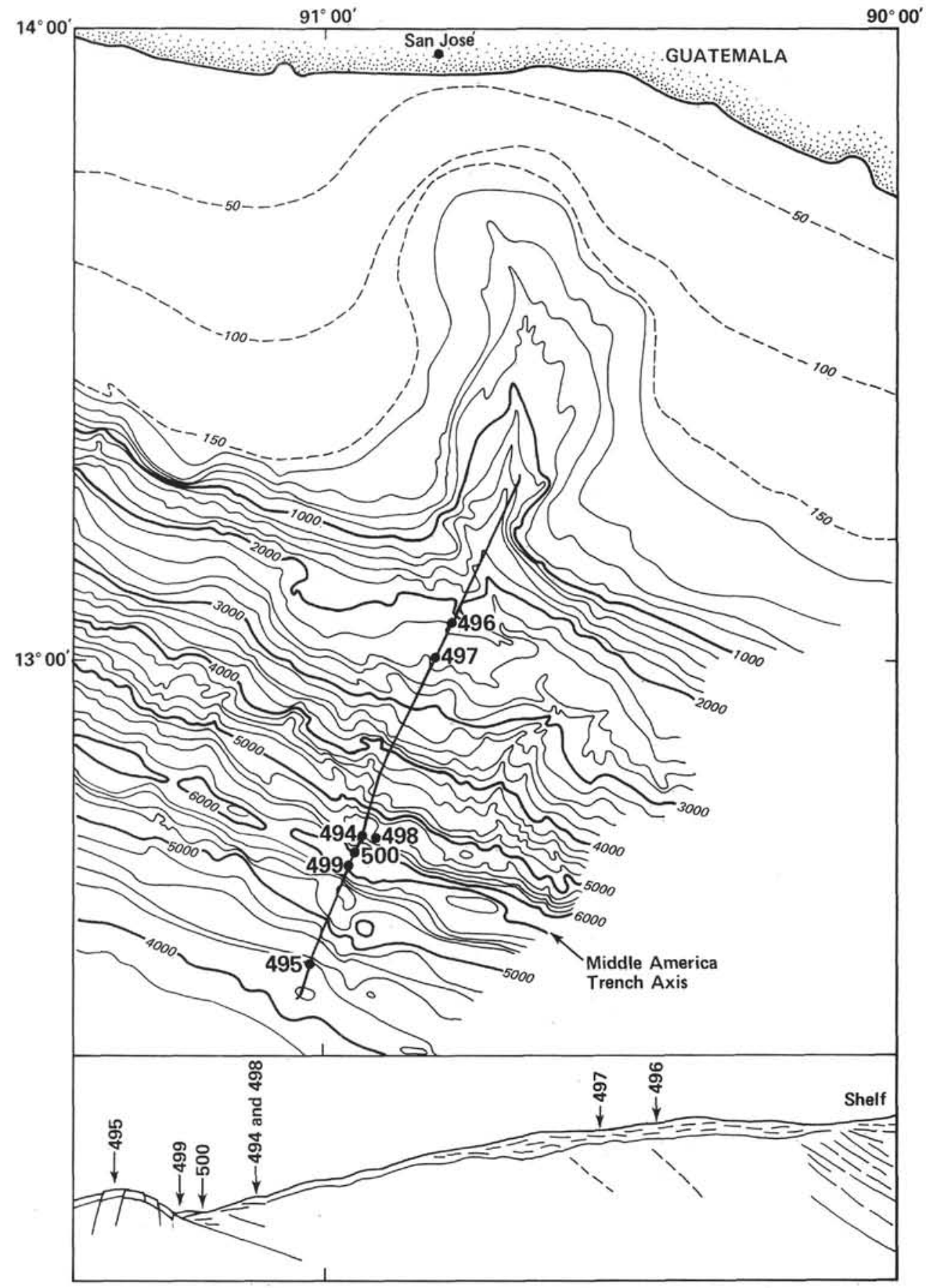

Figure 1. Location map for DSDP Leg 67 sites off Guatemala.

biogenic, siliceous mud and muddy ash with only $1 \%$ to $8 \%$ carbonate; traces of quartz appear at certain levels. The plagioclase feldspars are sometimes more abundant (Samples 499-13-6, 29-31 cm to 499-9-1, 105-107 cm). Argillaceous minerals were not detected.

\section{Site 494 (Table 4)}

Situated at the foot of the slope, the sediments studied are Late Cretaceous, Oligocene, Miocene, Pliocene, and Quaternary.
Hole $494 \mathrm{~A}$. The only sample studied from a Cretaceous formation (Sample 494A-29-2, 16-18 cm) is silty mudstone, represented in the bulk sediment by the absence of carbonates and by traces of quartz and plagioclase feldspars and in the $<2-\mu \mathrm{m}$ fraction by well-crystallized smectites and zeolites of the clinoptilolite type. The Eocene, Oligocene, and Miocene deposits show some traces of quartz and plagioclase feldspars. Some rare levels are carbonates (middle Eocene formations); the $<2-\mu \mathrm{m}$ fraction is characterized by the presence of smec- 
Table 1. X-ray diffraction analysis of bulk samples and the fine-grained $(<2-\mu \mathrm{m})$ fractions from Hole 495.

\begin{tabular}{|c|c|c|c|c|c|c|c|c|c|}
\hline \multirow[b]{2}{*}{$\begin{array}{l}\text { Core-Section } \\
\text { (interval in } \mathrm{cm} \text { ) }\end{array}$} & \multirow[b]{2}{*}{$\begin{array}{l}\text { Sub-bottom } \\
\text { Depth } \\
(\mathrm{m})\end{array}$} & \multicolumn{5}{|c|}{ Bulk Sediment } & \multicolumn{3}{|c|}{$<2-\mu \mathrm{m}$ Fraction } \\
\hline & & $\begin{array}{c}\text { Carbonate } \\
\text { Calcite } \\
(\%)\end{array}$ & Quartz & $\begin{array}{l}\text { Feldspar } \\
\text { (alkaline) }\end{array}$ & $\begin{array}{c}\text { Feldspar } \\
\text { (plagioclase) }\end{array}$ & Zeolite & $\begin{array}{c}\text { Smectites } \\
\left(\%_{0}\right)\end{array}$ & $\begin{array}{c}\text { Chlorites } \\
(\%)\end{array}$ & $\begin{array}{c}\text { Zeolites } \\
(\%)\end{array}$ \\
\hline $4-3,128-130$ & 32.79 & - & T & - & $T$ & - & - & - & - \\
\hline $6-4,29-31$ & 52.29 & - & T & - & T & - & T & - & - \\
\hline $9 \cdot 3,98-100$ & 79.98 & - & $\mathrm{T}$ & - & $\overline{-}$ & - & $T$ & - & - \\
\hline $11-3,45-47$ & 98.45 & - & $\dot{T}$ & - & T & - & - & - & - \\
\hline $13-3,41-43$ & 117.41 & - & $\dot{T}$ & - & $\mathrm{T}$ & - & - & - & - \\
\hline $14-1,62-64$ & 124.12 & $T$ & - & - & - & - & - & - & - \\
\hline $15-1,58-60$ & 133.58 & - & - & - & $T$ & - & - & - & - \\
\hline $16-7,30-32$ & 151.80 & - & - & - & - & - & - & - & - \\
\hline $17-6,53-55$ & $\begin{array}{l}160.03 \\
1603\end{array}$ & $\bar{T}$ & $\overline{-}$ & $=$ & $\bar{T}$ & - & - & - & - \\
\hline $18-5,28-30$ & 167,68 & - & - & - & 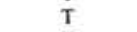 & - & - & - & - \\
\hline $19-2,110-112$ & 173.60 & $=$ & - & - & $\mathrm{T}$ & - & - & - & - \\
\hline $21-4,23-25$ & 194.73 & 83.8 & - & - & - & - & $T$ & - & - \\
\hline $23-1,21-24$ & 209.21 & 83.8 & - & - & - & - & 100 & - & - \\
\hline $25-2,9-11$ & 229.59 & 74 & - & - & - & - & $\mathrm{T}$ & - & - \\
\hline $26-3,80-82$ & 241.30 & 81 & - & - & - & - & - & - & - \\
\hline $28-5,75-77$ & 263.25 & 66 & - & - & - & - & - & - & - \\
\hline $30-2,120-122$ & 278.20 & 75 & - & - & - & - & - & - & - \\
\hline $32-4,130-105$ & 300.03 & 83 & - & - & - & - & - & - & - \\
\hline $34-3,22-24$ & 316.72 & 90 & - & $=$ & - & - & - & - & - \\
\hline $39-2,98-100$ & 363.48 & 88 & $=$ & $\overline{-}$ & $=$ & - & $\bar{T}$ & - & - \\
\hline $42-5,74-76$ & 396.24 & 89 & - & - & - & - & 100 & - & - \\
\hline $44-6,31-33$ & 416.31 & 94 & $=$ & $\overline{-}$ & $\overline{-}$ & - & 100 & $\bar{z}$ & $=$ \\
\hline $45-4,98-100$ & $\begin{array}{l}410.31 \\
423.48\end{array}$ & 82 & $=$ & $=$ & $=$ & - & 100 & & \\
\hline $46-1,28-30$ & 427.78 & 84 & - & - & - & - & $T$ & - & - \\
\hline
\end{tabular}

Note: $T=$ trace.

Table 2. X-ray diffraction analysis of bulk samples and the fine-grained $(<2-\mu \mathrm{m})$ fractions from Hole 500 .

\begin{tabular}{|c|c|c|c|c|c|c|c|c|c|}
\hline \multirow[b]{2}{*}{$\begin{array}{l}\text { Core-Section } \\
\text { (interval in } \mathrm{cm} \text { ) }\end{array}$} & \multirow[b]{2}{*}{$\begin{array}{l}\text { Sub-bottom } \\
\text { Depth } \\
\text { (m) }\end{array}$} & \multicolumn{5}{|c|}{ Bulk Sediment } & \multicolumn{3}{|c|}{$<2-\mu \mathrm{m}$ Fraction } \\
\hline & & $\begin{array}{c}\text { Carbonate } \\
\text { Calcite } \\
(\%)\end{array}$ & Quartz & $\begin{array}{l}\text { Feldspar } \\
\text { (alkaline) }\end{array}$ & $\begin{array}{c}\text { Feldspar } \\
\text { (plagioclase) }\end{array}$ & Zeolite & $\begin{array}{c}\text { Smectites } \\
(\%)\end{array}$ & $\begin{array}{c}\text { Chlorites } \\
(\%)\end{array}$ & $\begin{array}{c}\text { Zeolites } \\
(\%)\end{array}$ \\
\hline $1.3,13-15$ & 3.13 & 5 & $\mathrm{~T}$ & - & $\mathrm{T}$ & - & $\mathrm{T}$ & - & - \\
\hline $4-3,60-62$ & 27.10 & 8 & $\dot{T}$ & - & $\dot{p}$ & - & - & - & - \\
\hline $5-2,8-10$ & 34.58 & 6 & $\mathrm{~T}$ & - & $\mathrm{T}$ & - & $\mathrm{T}$ & - & - \\
\hline $8, \mathrm{CC}(25-28)$ & 70.85 & 7 & $\mathrm{~T}$ & - & $\mathbf{P}$ & - & - & - & - \\
\hline $10-3,29-81$ & 83.79 & 87 & - & - & - & - & - & - & - \\
\hline $14-2,15-17$ & 120.15 & 88 & - & - & - & - & - & - & - \\
\hline $15-5,37-39$ & 134.37 & 90 & - & - & - & - & - & - & - \\
\hline
\end{tabular}

Note: $\mathrm{T}=$ trace: $\mathrm{P}=$ present.

Table 3. X-ray diffraction analysis of bulk samples and the fine-grained $(<2-\mu \mathrm{m})$ fractions from Holes 499 and 499B.

\begin{tabular}{|c|c|c|c|c|c|c|c|c|c|}
\hline \multirow[b]{2}{*}{$\begin{array}{l}\text { Core-Section } \\
\text { (interval in } \mathrm{cm} \text { ) }\end{array}$} & \multirow[b]{2}{*}{$\begin{array}{l}\text { Sub-bottom } \\
\text { Depth } \\
\text { (m) }\end{array}$} & \multicolumn{5}{|c|}{ Bulk Sediment } & \multicolumn{3}{|c|}{$<2-\mu \mathrm{m}$ Fraction } \\
\hline & & $\begin{array}{c}\text { Carbonate } \\
\text { Calcite } \\
(\%)\end{array}$ & Quartz & $\begin{array}{l}\text { Feldspar } \\
\text { (alkaline) }\end{array}$ & $\begin{array}{c}\text { Feldspar } \\
\text { (plagioclase) }\end{array}$ & Zeolite & $\begin{array}{c}\text { Smectites } \\
(\%)\end{array}$ & $\begin{array}{c}\text { Chlorites } \\
(\%)\end{array}$ & $\begin{array}{c}\text { Zeolites } \\
(\%)\end{array}$ \\
\hline \multicolumn{10}{|l|}{ Hole 499} \\
\hline $1-1,129-131$ & 1.29 & 2 & $\mathrm{~T}$ & - & $T$ & - & - & - & - \\
\hline $3-4,68-70$ & 15.68 & 2 & $\mathbf{T}$ & - & $\mathrm{T}$ & - & - & - & - \\
\hline $5-1,12-14$ & 29.62 & 4 & $\mathrm{~T}$ & - & $\mathrm{T}$ & - & $\mathbf{T}$ & - & - \\
\hline $6-2,7-9$ & 40.57 & 3 & T & - & $\mathrm{T}$ & - & $\mathbf{T}$ & - & - \\
\hline $9-1,105-107$ & 68.55 & 6 & $\mathrm{~T}$ & - & $\mathbf{P}$ & - & - & - & - \\
\hline $11-1,96-98$ & 87.46 & 4 & - & - & $P$ & - & - & - & - \\
\hline $12-3,79-81$ & 99.29 & 8 & - & - & $\mathrm{P}$ & - & - & - & - \\
\hline $13-6,29-31$ & 113.29 & 2 & $\mathrm{~T}$ & - & $\mathrm{P}$ & - & $\bar{m}$ & - & - \\
\hline $14-2,74-76$ & 117.24 & 1 & $\mathrm{~T}$ & - & $\mathrm{T}$ & - & $\mathrm{T}$ & - & - \\
\hline $18-3,31-33$ & 156.31 & 5 & T & - & $\mathrm{T}$ & - & $T$ & - & - \\
\hline $22-3,57-59$ & 194.57 & 2 & $\mathrm{~T}$ & - & $\mathbf{T}$ & - & $T$ & - & - \\
\hline $23-3,105-107$ & 204.55 & 63 & - & - & - & - & $T$ & - & - \\
\hline $24-1,87-89$ & 210.87 & 64 & - & - & - & - & 100 & - & - \\
\hline $25-4,84-86$ & 224.84 & 69 & - & - & - & - & 100 & - & - \\
\hline \multicolumn{10}{|l|}{ Hole 499B } \\
\hline $2-2,63-65$ & 10.13 & 67 & - & - & - & - & 100 & - & - \\
\hline $4-3,27-31$ & 31.77 & 87 & - & - & - & - & - & - & - \\
\hline $9, \mathrm{CC}(17-19)$ & 84.5 & 87 & - & - & - & - & 100 & - & - \\
\hline
\end{tabular}

Note: $\mathrm{T}=$ trace; $\mathrm{P}=$ present. 


\section{LATOUCHE, N. MAILLET}

Table 4. X-ray diffraction analysis of bulk samples and the fine-grained $(<2-\mu \mathrm{m})$ fractions from Holes 494 and 494A.

\begin{tabular}{|c|c|c|c|c|c|c|c|c|c|}
\hline \multirow[b]{2}{*}{$\begin{array}{l}\text { Core-Section } \\
\text { (interval in } \mathrm{cm} \text { ) }\end{array}$} & \multirow[b]{2}{*}{$\begin{array}{l}\text { Sub-bottom } \\
\text { Depth } \\
\text { (m) }\end{array}$} & \multicolumn{5}{|c|}{ Bulk Sediment } & \multicolumn{3}{|c|}{$<2-\mu \mathrm{m}$ Fraction } \\
\hline & & $\begin{array}{c}\text { Carbonate } \\
\text { Calcite } \\
(\%)\end{array}$ & Quartz & $\begin{array}{c}\text { Feldspar } \\
\text { (alkaline) }\end{array}$ & $\begin{array}{c}\text { Feldspar } \\
\text { (plagioclase) }\end{array}$ & Zeolite & $\begin{array}{c}\text { Smectites } \\
(\%)\end{array}$ & $\begin{array}{c}\text { Chlorites } \\
(\%)\end{array}$ & $\begin{array}{c}\text { Zeolites } \\
\left(\%_{0}\right)\end{array}$ \\
\hline \multicolumn{10}{|l|}{ Hole 494} \\
\hline $1-1,10-12$ & 0.10 & - & T & - & T & - & 85 & 15 & - \\
\hline $2-3,95-97$ & 12.95 & - & $\mathrm{T}$ & - & $\mathrm{T}$ & - & $\mathrm{T}$ & $\mathrm{T}$ & - \\
\hline $4-3,59-61$ & 31.59 & - & $\dot{T}$ & - & $\tau$ & - & $\dot{T}$ & $\dot{T}$ & - \\
\hline \multicolumn{10}{|l|}{ Hole $494 \mathrm{~A}$} \\
\hline $\mid-1,42-44$ & 37.92 & - & $\mathrm{T}$ & - & T & - & $T$ & $\mathrm{~T}$ & - \\
\hline $5=1,13-15$ & 75.63 & - & $\dot{T}$ & - & $\dot{T}$ & - & $\dot{T}$ & $T$ & - \\
\hline $8-1,68-70$ & 104.68 & - & - & - & T & - & T & - & - \\
\hline $9-2,8-10$ & 115.08 & - & $\bar{T}$ & - & $\mathrm{T}$ & - & $T$ & - & - \\
\hline $11-1,126-128$ & 133.76 & - & $\mathrm{T}$ & - & $\mathrm{T}$ & - & $\mathrm{T}$ & - & - \\
\hline $\mid 5-1,39-41$ & 170.89 & - & T & - & $T$ & - & - & - & - \\
\hline $17-1,87-89$ & 190.37 & $T$ & $\dot{T}$ & - & $\dot{T}$ & - & - & - & - \\
\hline $19-2,20-22$ & 210.20 & 46 & T & - & $T$ & - & T & - & - \\
\hline $20-5,131-133$ & 225.31 & - & $\dot{T}$ & - & $\mathrm{T}$ & - & $\mathrm{T}$ & - & - \\
\hline $22-2,8-10$ & 238.58 & - & $\dot{T}$ & - & $\mathrm{T}$ & - & 100 & - & - \\
\hline $25-1,30-31$ & 265.80 & 35 & T & - & $\mathrm{T}$ & - & 100 & - & - \\
\hline $27-1,45-47$ & 284.95 & 29 & $\mathrm{~T}$ & $=$ & $\mathrm{T}$ & $=$ & 100 & $=$ & $=$ \\
\hline $29-2,16-18$ & 304.66 & - & T & - & $\mathrm{T}$ & - & 67 & - & Clinoptilolites \\
\hline
\end{tabular}

Note: $\mathrm{T}=$ trace; $\mathrm{P}=$ present .

tites. The Pliocene formations (Samples 494A-19-2, 20$22 \mathrm{~cm}$ and $494 \mathrm{~A}-17-1,87-89 \mathrm{~cm}$ ) are mudstone nearly devoid of carbonates; quartz and feldspars are present in traces. Argillaceous minerals are absent.

The Quaternary sediments (Samples 494A-15-1, 39$41 \mathrm{~cm}$ to $494 \mathrm{~A}-1-1,10-12 \mathrm{~cm}$ ) are mudstone and siliceous mud characterized by traces of quartz and plagioclase. One $<2-\mu \mathrm{m}$ fraction also shows argillaceous minerals with lightly outlined smectites, and some traces of chlorites appear toward the topmost levels.

Hole 494. The samples studied are Quaternary (Samples 494- core 4-3, 59-61 cm to 494-1-1, 10-12 cm) and contain siliceous mud represented by traces of quartz and plagioclase feldspars; the very slightly crystallized argillaceous minerals that occur are smectites with some rare chlorites.

\section{Site 498 (Table 5)}

The two holes drilled at Site 498 are very close to Site 494 (498A-Sample 498A-13-1, 38-40 to 498A-5-3, 8$10 \mathrm{~cm}$ and 498-Sample 498-1-3, 17-19 cm). Analysis of the mudstone and siliceous mud reveals between $1 \%$ and $8 \%$ carbonate only; quartz and feldspars are present in traces. The $<2-\mu \mathrm{m}$ fractions are poorly crystallized. Among the argillaceous levels one can distinguish traces of smectites and an outline of chlorite.

Table 5. X-ray diffraction analysis of bulk samples and the fine-grained $(<2-\mu \mathrm{m})$ fractions from Holes 498 and 498A.

\begin{tabular}{|c|c|c|c|c|c|c|c|c|c|}
\hline \multirow[b]{2}{*}{$\begin{array}{c}\text { Core-Section } \\
\text { (interval in cm) }\end{array}$} & \multirow[b]{2}{*}{$\begin{array}{l}\text { Sub-bottom } \\
\text { Depth } \\
\text { (m) }\end{array}$} & \multicolumn{5}{|c|}{ Bulk Sediment } & \multicolumn{3}{|c|}{$<2-\mu \mathrm{m}$ Fraction } \\
\hline & & $\begin{array}{c}\text { Carbonate } \\
\text { Calcite } \\
(\%)\end{array}$ & Quartz & $\begin{array}{c}\text { Feldspar } \\
\text { (alkaline) }\end{array}$ & $\begin{array}{c}\text { Feldspar } \\
\text { (plagioclase) }\end{array}$ & Zeolite & $\begin{array}{c}\text { Smectites } \\
(\%)\end{array}$ & $\begin{array}{c}\text { Chlorites } \\
(\%)\end{array}$ & $\begin{array}{c}\text { Zeolites } \\
(\%)\end{array}$ \\
\hline \multicolumn{10}{|l|}{ Hole 498} \\
\hline $1-3,17-19$ & 3.17 & 8 & T & - & $T$ & - & T & - & - \\
\hline \multicolumn{10}{|l|}{ Hole 498A } \\
\hline $\begin{array}{l}5-3,8-10 \\
8-2,16-18\end{array}$ & $\begin{array}{l}215.08 \\
242.16\end{array}$ & $\begin{array}{l}1 \\
8\end{array}$ & T & $\overline{-}$ & $\begin{array}{l}\mathrm{T} \\
\mathrm{T}\end{array}$ & $\overline{-}$ & T & $\underline{T}$ & $\overline{-}$ \\
\hline $13-1,38-40$ & 288.38 & 3 & $\mathrm{~T}$ & - & $\mathrm{T}$ & - & $\mathrm{T}$ & - & - \\
\hline
\end{tabular}

Note: $\mathrm{T}=$ trace.

Table 6. X-ray diffraction analysis of bulk samples and the fine-grained $(<2-\mu \mathrm{m})$ fractions from Hole 497.

\begin{tabular}{|c|c|c|c|c|c|c|c|c|c|}
\hline \multirow[b]{2}{*}{$\begin{array}{c}\text { Core-Section } \\
\text { (interval in } \mathrm{cm} \text { ) }\end{array}$} & \multirow[b]{2}{*}{$\begin{array}{l}\text { Sub-bottom } \\
\text { Depth } \\
\text { (m) }\end{array}$} & \multicolumn{5}{|c|}{ Bulk Sediment } & \multicolumn{3}{|c|}{$<2-\mu \mathrm{m}$ Fraction } \\
\hline & & $\begin{array}{c}\text { Carbonate } \\
\text { Calcite } \\
(\%)\end{array}$ & Quartz & $\begin{array}{l}\text { Feldspar } \\
\text { (alkaline) }\end{array}$ & $\begin{array}{c}\text { Feldspar } \\
\text { (plagioclase) }\end{array}$ & Zeolite & $\begin{array}{c}\text { Smectites } \\
(\%)\end{array}$ & $\begin{array}{c}\text { Chlorites } \\
(\% 0)\end{array}$ & $\begin{array}{c}\text { Zeolites } \\
\left(\sigma_{0}\right)\end{array}$ \\
\hline $11-3,38-40$ & 95.88 & 5 & $\mathrm{~T}$ & - & $\mathrm{T}$ & - & $\mathrm{T}$ & - & - \\
\hline $15-5,27-29$ & 136.79 & 5 & $\mathrm{~T}$ & - & $T$ & - & T & $\mathrm{T}$ & - \\
\hline $16-5,63-65$ & 146.63 & 2 & $\mathrm{~T}$ & - & $T$ & - & P & $\mathrm{T}$ & - \\
\hline $19-4,21-23$ & 173.21 & 2 & $T$ & - & P & - & $\mathrm{T}$ & $T$ & - \\
\hline $23-3,6-8$ & 209.56 & 3 & $\mathrm{~T}$ & - & $T$ & - & $\mathrm{T}$ & - & - \\
\hline $34-3,30-32$ & 314.30 & 1 & $\mathrm{~T}$ & - & P & - & 100 & - & - \\
\hline $39-3,93-95$ & 362.43 & 4 & $T$ & - & $T$ & - & 100 & $\mathrm{~T}$ & - \\
\hline $40-5,90-92$ & 374.90 & 7 & $\mathrm{~T}$ & - & $\mathrm{T}$ & - & 100 & - & - \\
\hline $42-8,36-39$ & 396.36 & 3 & $T$ & - & $T$ & - & 100 & - & - \\
\hline
\end{tabular}

Note: $\mathrm{T}=$ trace; $\mathrm{P}=$ present. 


\section{Site 497 (Table 6)}

The sediments studied are Pliocene and Quaternary and were cored from the upper continental slope. The lower Pliocene sediments (Samples 497-42-8, 36-39 cm to $497-34-3,30-32 \mathrm{~cm}$ ) are nannofossil mudstone and hemipelagic mud scarce in carbonate; there are traces of quartz and feldspars, and the $<2-\mu \mathrm{m}$ fraction shows argillaceous minerals of the smectite type.

The Pliocene and Quaternary deposits (Samples 497$23-3,6-8 \mathrm{~cm}$ to $497-11-3,38-40 \mathrm{~cm}$ ) are siliceous mud and hemipelagic mud equally poor in carbonates and containing only traces of quartz and feldspars. The argillaceous deposits are very badly crystallized and are represented by traces of smectites and some rare traces of chlorites. This site is characterized by more clearly individualized plagioclases (two samples are relatively richer: Sample 497-19-4, 21-23 cm and Sample 497-34$3,30-32 \mathrm{~cm}$ ).

\section{Site 496 (Table 7)}

This site is situated on the continental slope; of the Leg 67 drill sites, it is the nearest to the continent. The sediments drilled are Miocene, Pliocene, and Quaternary. The lower and middle Miocene deposits (Samples $496-40-8,19-23 \mathrm{~cm}$ to $496-30-6,20-22 \mathrm{~cm}$ ) are mudstone containing little carbonate; quartz appears in traces, however, plagioclase feldspars are clearly present. The few argillaceous minerals are represented by smectites and some chlorites. The Miocene and the lower Pliocene (Samples 496-28-3, 53-55 cm and 496-25-4, 132$134 \mathrm{~cm}$ ) nannofossil mud and sandy mud above are carbonate-poor, but Sample 496-25-4, 132-134 cm reveals traces of dolomite. Quartz occurs in traces, and plagioclases are present. Argillaceous minerals are absent. The Quaternary sediments (Samples 496-16-1, 52-54 cm to 496-2-3, 92-94 cm; Cores 16 to 12 containing nannofossil mud and Cores 12 to 2 , siliceous mud) are very poor in carbonate (but Sample 496-14-2, 61-63 cm contains $11 \%$ dolomite). Quartz occurs in traces; plagioclases are present in the lowest levels and then present in traces to the top of the sequence. Sometimes traces of alkaline feldspars are observed. The argillaceous minerals are rare; one can recognize, however, some traces of smectites and sometimes chlorites. As in Hole 497, the plagioclase feldspars are relatively frequent. The presence of alkaline feldspars in traces and also of dolomites in some samples is a particularity of Hole 496.

\section{GENERAL OUTLINE OF THE MINERALOGY OF DEPOSITS}

The deposits X-rayed are carbonate and siliceous biogenic formations. Generally, the crystallized minerals have been weakly detected, in the total sediment as well as in the $<2-\mu \mathrm{m}$ fractions. This is certainly because of dilution of these minerals in a very abundant, amorphous phase. Indeed, the biogenic siliceous levels are very frequent and could contribute in large part to this dilution. Cook and Zemmels (1972) noted the same phenomenon in the Leg 9 samples.

The examination of the $<2-\mu \mathrm{m}$ fraction under electronic transmission microscope also revealed the very low quantity of crystallized argillaceous minerals and the prevalence of either fragments of diatoms or of nonidentifiable dark fragments (Plates 1 and 2).

In spite of the paucity of minerals present, the X-ray diffractometer allowed us to make the following observations on mineralogical sequences (Fig. 2): At the sites farthest offshore $(495,500,499,494)$, the carbonates, essentially calcite, are mainly Miocene or older. Minerals such as quartz, feldspars, and clays are essentially Quaternary formations at these same sites, although these minerals are present in all the sedimentary columns of the holes high on the slope. Plagioclase or alkaline feldspars, dolomites, zeolites, smectites, and chlorites are present in varying abundance, more or less according to the geographical area. Smectites are generally found in the carbonate formations of the holes farthest from the coast and in the oldest levels of the holes on the slope. Plagioclase feldspars are noticeable only in the higher cores of Holes 500 and 499, however, they are present throughout the sediment columns of the holes drilled on the slope (496 and 497). Alkaline feldspars and dolomite were found only in Hole 496, the closest to

Table 7. X-ray diffraction analysis of bulk samples and the fine-grained $(<2-\mu \mathrm{m})$ fractions from Hole 496.

\begin{tabular}{|c|c|c|c|c|c|c|c|c|c|}
\hline \multirow[b]{2}{*}{$\begin{array}{l}\text { Core-Section } \\
\text { (interval in } \mathrm{cm} \text { ) }\end{array}$} & \multirow[b]{2}{*}{$\begin{array}{l}\text { Sub-bottom } \\
\text { Depth } \\
\text { (m) }\end{array}$} & \multicolumn{5}{|c|}{ Bulk Sediment } & \multicolumn{3}{|c|}{$<2-\mu \mathrm{m}$ Fraction } \\
\hline & & $\begin{array}{c}\text { Carbonate } \\
\text { Calcite } \\
(\%)\end{array}$ & Quartz & $\begin{array}{l}\text { Feldspar } \\
\text { (alkaline) }\end{array}$ & $\begin{array}{c}\text { Feldspar } \\
\text { (plagioclase) }\end{array}$ & Zeolite & $\begin{array}{c}\text { Smectites } \\
(\%)\end{array}$ & $\begin{array}{c}\text { Chlorites } \\
(\%)\end{array}$ & $\begin{array}{c}\text { Zeolites } \\
(\%)\end{array}$ \\
\hline $2-3,92-94$ & 11.42 & 3 & $T$ & - & $\mathrm{T}$ & - & $\mathrm{T}$ & $T$ & - \\
\hline $6-3,41-43$ & 48.91 & 2 & $\mathrm{~T}$ & - & $\mathrm{T}$ & - & $\mathrm{T}$ & - & - \\
\hline $9-2,61-63$ & 76.11 & 4 & $\mathrm{~T}$ & $\mathrm{~T}$ & $\dot{T}$ & - & $\mathrm{T}$ & $T$ & - \\
\hline $10-3,32-34$ & 86.82 & 5 & $\dot{T}$ & - & $\dot{T}$ & - & $\mathrm{T}$ & $\mathrm{T}$ & - \\
\hline $11-1,33-35$ & 93.33 & 5 & $\dot{T}$ & $\mathrm{~T}$ & $\dot{T}$ & - & $\mathrm{T}$ & $\mathrm{T}$ & - \\
\hline $12-2,61-63$ & 104.61 & 8 & $T$ & - & $\mathrm{T}$ & - & $\mathrm{T}$ & $T$ & - \\
\hline $13-1,61-63$ & 112.61 & 7 & $\mathrm{~T}$ & - & P & - & $\mathrm{T}$ & $T$ & - \\
\hline $14-2,61-63$ & 123.61 & $11+(11)$ & 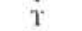 & - & $\mathrm{P}$ & - & - & - & - \\
\hline $15-2,62-64$ & 133.12 & 13 & $T$ & - & p & - & $\mathrm{T}$ & $T$ & - \\
\hline $16-1,52-54$ & 140.62 & 3 & $\mathrm{~T}$ & - & $\mathrm{T}$ & - & $\mathrm{T}$ & $T$ & - \\
\hline $25-1,132-134$ & 231.82 & $8(T)$ & $\mathrm{T}$ & $\mathrm{T}$ & $\mathrm{P}$ & - & - & - & - \\
\hline $28-3,53-55$ & 258.03 & 4 & $\dot{T}$ & - & $\mathrm{P}$ & - & - & - & - \\
\hline $30-6,20-22$ & 281.20 & 5 & $\dot{T}$ & - & P & - & $\mathrm{T}$ & - & - \\
\hline $31-3,18-20$ & 286.18 & 5 & $\mathrm{~T}$ & - & P & - & 81 & 19 & - \\
\hline $40-8,19-23$ & 377.49 & 6 & $\dot{T}$ & - & $\mathrm{T}$ & - & 82 & 18 & - \\
\hline
\end{tabular}

Note: $\mathrm{T}=$ trace; $\mathrm{P}=$ present; $(\mathrm{)}=$ dolomite. 


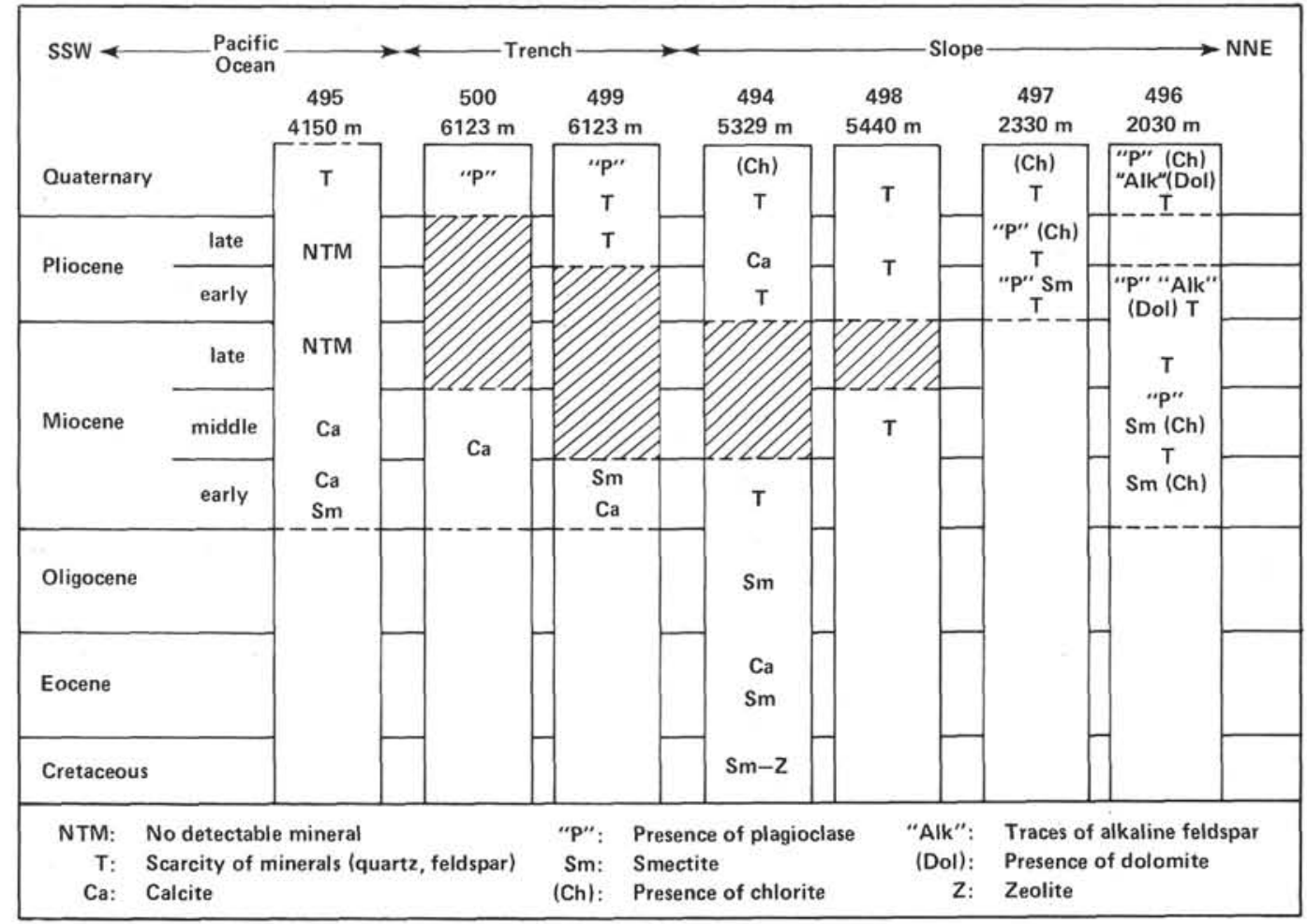

Figure 2. Schematic diagram of the mineralogical assemblages.

the Guatemalan coast. Chlorites, although barely detected, are present only in the most recent sediments of the slope. In Hole 496, however, chlorites are encountered in all the formations. Zeolites (clinoptilolites) were detected in only one level of Hole 494A; this level is Cretaceous and therefore should contain zeolitic formations (Cores 29 to 35, Site 494 report).

In conclusion, apart from the presence of biogenic carbonates represented in the oldest deposits, the crystallized fine fractions indicate the following distributions:

1) Spatially, the abundance of minerals decreases from the slope towards the deep ocean.

2) Chronologically, the crystallized fraction is better represented in the most recent levels.

This pattern shows that the drift of sediment of terrigenous origin is minimal and is perceptible only in the sites closest to the coast.

\section{ACKNOWLEDGMENTS}

This study was supported by Centre National de la Recherche Scientifique (CNRS), France. The entire text and illustrations benefited from the reviews of J. Aubouin and R. Blanchet, whose critical reading and valuable suggestions for improvement we greatly appreciate.

\section{REFERENCES}

Brown, G., and Brindley, G. W. (Eds.), 1961. The X-ray Identification and Crystal Structure of Clay Minerals: London (Mineralogical Soc.).

Cook, H. E., and Zemmels, I., 1972. X-ray mineralogy studies, Leg 9. In Hays, J. D., et al., Init. Repts. DSDP, 9: Washington (U.S. Govt. Printing Office), 707-778.

Thorez, J., 1975. Phyllosilicates and Clay Minerals: a Laboratory Handbook for their X-ray Diffraction Analysis: Dison, Belgique (Lelotte). 


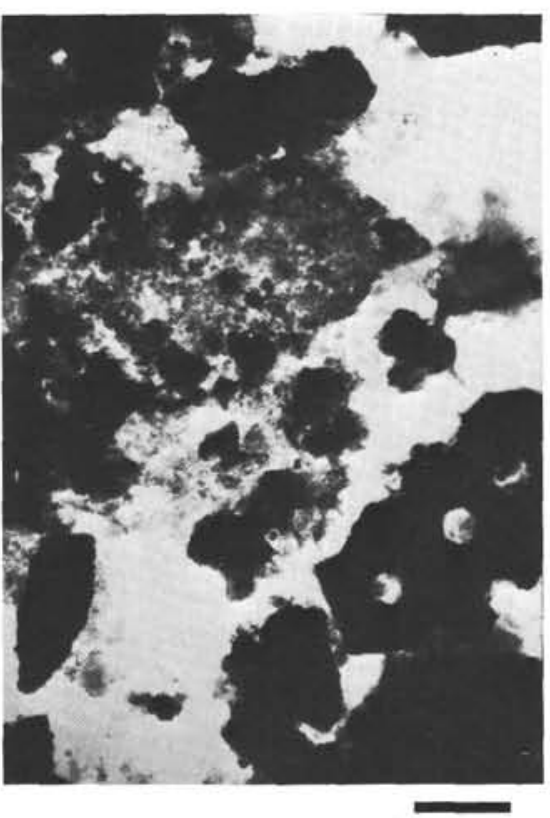

Plate 1. Transmission electron micrograph of diatom fragments. (Scale bar is $1 \mu \mathrm{m}$ long).

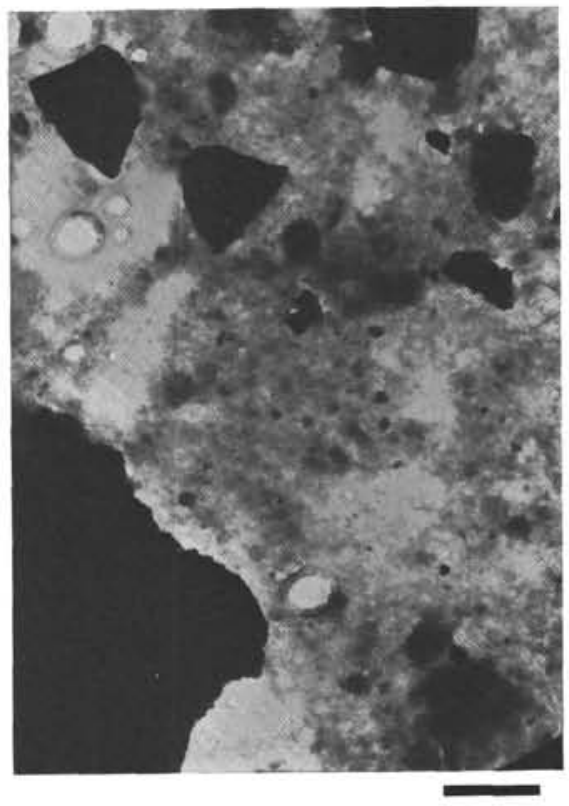

Plate 2. Transmission electron micrograph of nonidentified fragments. (Scale bar is $1 \mu \mathrm{m}$ long.) 